\title{
Lusotopie
}

Recherches politiques internationales sur les espaces

issus de l'histoire et de la colonisation portugaises

XII(1-2) | 2005

Genre et rapports sociaux

\section{Masculinities, Violence and Power in Timor Leste}

Masculinités, violence et pouvoir au Timor oriental.

Masculinidades, Violência e Poder em Timor-Leste

\section{Henri Myrttinen}

\section{(2) OpenEdition \\ Journals}

Electronic version

URL: https://journals.openedition.org/lusotopie/1262

ISSN: 1768-3084

Publisher

Idemec - UMR 7307

Printed version

Date of publication: 30 November 2005

Number of pages: $233-244$

ISSN: 1257-0273

Electronic reference

Henri Myrttinen, "Masculinities, Violence and Power in Timor Leste", Lusotopie [Online], XII(1-2) | 2005,

Online since 30 mars 2016, connection on 28 juin 2022. URL: http://journals.openedition.org/

lusotopie/1262 


\section{MASGULINITIES, VIOLENGE AND POWER IN TIMOR LESTE}

This article sketches some of the manifestations of violent masculinities which were visible in the Timor Leste conflict from 1975 to 1999. While concentrating on Timorese actors, it points out that this does not in any way mean that Timorese men are inherently more violent than others. In fact, the vast majority of the acts of violence during the conflict were committed by members of the occupying Indonesian security forces. After a brief thematic and historical introduction, the article examines manifestations of violent masculinities within the pro-independence Falintil guerrilla, the pro-Indonesian militias and the civilian population.

As the end of the conflict has not meant an end to, but a "domestication" of violence with extremely high rates of domestic and gender-based sexual violence, the article further examines the impact of the post-conflict situation on violent manifestations of masculinity.

\section{Masculinités, la violence et le pouvoir à Timor oriental}

Cet article esquisse quelques-unes des manifestations violentes de la masculinité qui ont été visibles au cours du conflit de Timor Leste entre 1975 et 1999. Bien que relatif aux acteurs timorais, il ne saurait en aucun cas signifier que les hommes timorais soient fondamentalement plus violents que les autres. En réalité, au cours du conflit, la grande majorité des actes de violence ont été commis par des membres des forces de sécurité des occupants indonésiens. Après une brève introduction thématique et historique, l'article examine les manifestations violentes de la masculinité entre la guérilla indépendantiste des Falintil, les milices pro-indonésiennes et la population civile.

Étant donné que la fin du conflit n’a pas constitué une fin mais seulement une «domestication» de la violence, avec des taux extrêmement élevés de violence sexuelle domestique et de type sexiste, l'article examine en outre l'impact de la situation d'après-guerre sur les manifestations violentes de la masculinité.

Ocupação, resistência, domínio e patriarquismo:

Notas sobre Masculinidades, Violência e Poder em Timor-Leste

Este artigo esboça algumas das manifestações de masculinidades violentas que são visíveis no conflito de Timor-Leste no período de 1975-1999. Sublinha-se que a concen-tração sobre os actores timorenses de modo nenhum significa que os homens timorenses que os homens timorenses são intrinsecamente mais violentos do que outros. De facto, a grande maioria dos actos de violência durante o conflito foi perpetrada por membros das forças de segurança ocupantes indonésias. Após uma breve introdução temática e histórica, o artigo examina manifestações de masculinidades violentas no seio da guerrilha independentista das Falintil, das milícias indonésias e da população civil.

Como o fim do conflito não trouxe o fim da violência, mas sim a sua «domesticação" com elevada taxa de violência sexual interna e baseada no género, o artigo examina ainda o impacto da situação pós-conflito sobre manifestações violentas de masculinidade. 
$\mathrm{T}$ imor Leste emerged as the world's newest nation-state on 20 May 2002, ending an often violent history of foreign domination which lasted almost half a millennium. Independence ended approximately 450 years of Portuguese colonial rule, a short but brutal intermezzo under Japanese military occupation during World War II, 24 years under Indonesian occupation and a more benign 2 years under the United Nations Transitional Administration in East Timor (UNTAET). This history of foreign domination is also a history of resistance and violence, violence which often took on the form of sexualised violence against both women and men.

Regaining independence has however not meant an end to violence. While there is no longer an armed conflict in the country, Timorese society is beset by extremely high rates of domestic violence and latent political social conflict which has the potential of spilling over into overt violence. As so often, the common denominator linking these different forms of violence and different power struggles from different eras is that the majority of the perpetrators are men, usually young men.

In this article, I hope to briefly sketch some of the different forms that violent masculinity has taken in Timor Leste. For practical reasons, the article will concentrate on the period from 1974 to the present, starting with the end of the Portuguese period ushered in by the Carnation Revolution, followed by the brief civil war in 1975, the Indonesian invasion and ensuing "post-colonial colonialism, ${ }^{1}{ }$ the cataclysmic violence surrounding the 1999 referendum and finally post-conflict Timor Leste.

The reason why this article concentrates on men and particularly on violent masculinities is that by looking at the perpetrators of violence, I hope we can begin to learn more about the roots of violent conflict. The inherent danger of this focus is of course that, once again, the story of women and the role they played and continue to play remains untold. In order to avoid this, I shall try weave in the story of Timor Leste's women into my article. Primarily, however, I shall look at men. As Robert Morrell ${ }^{2}$ argued for South African history:

«It is true that South African history has been written as a story of men. But it is not true that South African history is about men. The difficulty lies in the notion of man. Essentialist conceptions of man are the problem. Man is considered to have an essence - aggressive, violent, acquisitive, insensitive, unemotional. What is not problematised is his social identity. What is not acknowledged is the social construction of masculinity.»

Thus, as strange as it may sound, men have become almost as neglected a category as women.

${ }^{1}$ Many of those ultimately responsible for the violence in Timor Leste, starting with Gen. Suharto himself, had themselves fought in the Indonesian War of Independence against the Dutch colonial power.

${ }^{2}$ R. Morrell, From Boys to Gentlemen - Settler Masculinity in Colonial Natal 1880-1920, Pretoria, University of South Africa Press, 2001: 9. 


\section{Historical background}

From the 16th century onwards, what is now the Democratic Republic of Timor Leste was, mais ou menos, under Portuguese $\mathrm{control}^{3}$. For the greater part of the colonial period, the «colonial footprint» of Portugal was relatively light. Only a handful of Portuguese were in the territory, no systematic effort was made to teach Portuguese and even missionary activities of the Catholic Church were rather limited. One of the hallmarks of the Portuguese period was the sexual activity of the Europeans, be they monks, soldiers, or administrators ${ }^{4}$. Interestingly, this «tradition» was taken up to a degree by Portuguese peacekeepers deployed with the UN missions in Timor Leste. Being the only contingent without a strict curfew, they quickly developed a reputation for womanising and left numerous single mothers in their wake.

It was only in the late 19th and early 20th century that Portugal became more actively involved in the territory, introducing a plantation economy, a tighter control of the territory colonial administration, and limited education for an assimilado elite. The increasingly heavy involvement of Portugal also led to increased resistance and revolts, the most famous ones being those of Dom Boaventura ${ }^{5}$.

After the final repression of the revolts in 1912, the colony saw a period of relative calm and of increased development. This period came to an end in December 1941, when Australian and Dutch troops landed in Dili to pre-empt a possible Japanese invasion. In reaction, the Japanese Imperial Army occupied the territory, though de jure it remained under Portuguese rule for the duration of the war $^{6}$. In addition to the violence directly related to the fighting, thousands of Timorese women were also forced into prostitution as so-called «comfort women» by the Japanese military. In this, they were aided by the Portuguese governor at the time, who, «against the protests of other Portuguese officials», ordered local chiefs to provide the Japanese troops with young women. His justification was that by doing so, he would save European women from being raped?

The end of the war brought with it several decades of tranquillity and few changes (ordem sem progreso) until April 1974, when the Carnation Revolution brought down the Salazar/Caetano dictatorship. Unlike other Portuguese colonies, such as Angola, Guinea-Bissau and Mozambique, Portuguese Timor had not seen any independence movement per se, though a part of the handful of Timorese students studying in Portugal had been influenced by the radical anti-colonial writings coming out of the African colonies. But like for its African counterparts, decolonisation in Timor Leste was rapid, haphazard and thrust the ill-prepared territory as

\footnotetext{
For a more detailed history of Timor Leste, see C. Boxer, «Portuguese Timor: A Rough Island History», History, 10, 1960: 349-355 or J. Dunn, Timor: A People Betrayed, Sydney, ABC Books, 1996.

${ }^{4}$ D. Hicks, Tetum Ghosts and Kin - Fertility and Gender in East Timor, Long Grove, Waveland, 2004: 10.

${ }^{5} \mathrm{~J}$. Dunn, op. cit.: 16.

${ }^{6}$ For an overview of the Japanese occupation of Timor Leste, see K. Gото, Tensions of Empire - Japan and Southeast Asia in the Colonial and Post-Colonial World, Singapore, Singapore University Press, 2003: 24-38.

J. Jolliffe, «Timor's Haunted Women», in The Age, Sydney, 3 of November, 2001.
} 
a pawn into the Cold War chess game. Like in Angola and Mozambique, the result was decades of sustained violence.

In the case of Timor Leste, the decolonisation process led to a brief civil war between the more conservative and Portugal-oriented UDT (União Democrática Timorense) and the more radical Fretilin (Frente Revolucionária de Timor Leste Independente) in mid-1975. The left-leaning Fretilin emerged victorious, setting off alarm bells in Jakarta, Canberra and Washington, this being the year when Phnom Penh had fallen to the Khmer Rouge, Vientiane to the Pathet Lao and Saigon to the Vietcong, exacerbating fears of a further Southeast Asian «domino falling»".

Indonesia had already been involved in covert cross-border operations but waited for a green light from visiting U.S. President Gerald Ford and Secretary of State Henry Kissinger before launching a full invasion of Timor Leste on December 7, 1975. In the initial phase of the war, in which the Indonesian armed forces were pitted against the Falintil (Forças Armadas do Libertação Nacional de Timor Leste) and which lasted until roughly late 1979, approximately 200 000-300 000 people, or around a third of the population of the territory was killed.

After the initial phase, the guerrilla war of the Falintil continued on a smaller scale until the pull-out of the Indonesian security forces in late 1999. The territory was in effect under military occupation for 24 years, with the Indonesian armed forces committing serious human rights abuses against the civilian population, many of them sexualised. In many ways, these methods paralleled or copied those of death squads and «counter-insurgency» operations in Vietnam and Central America, very possibly due to the training given to Indonesian special forces by Australia, United Kingdom, Germany and especially the USA at the same facilities where Latin American special forces were trained, such as Fort Benning, home to the «School of the Americas» ${ }^{9}$.

${ }^{8}$ On Australian involvement, see D. Greenless \& R. Garran, Deliverance - The Inside Story of East Timor's Fight for Freedom, Crow's Nest, Allen and Unwin, 2002: 1-16; for U.S. involvement, see W. Blum, Killing Hope - U.S. Military and CIA Interventions Since World War II, 2003, London, Zed Books: 197-198; for Indonesian covert operations, see K. Conboy, Kopassus - Inside Indonesia's Special Forces, Sydney, Equinox Publishers, 2003: 205-235.

${ }^{9}$ On training in Australia, Western Europe and USA, see G. AdiTjondro, «Ninjas, Nanggalas, Monuments and Mossad Manuals - An Anthropology of Indonesian State Terror in East Timor», in J. Sluka (ed.), Death Squad: The Anthropology of State Terror, Philadelphia, University of Pennsylvania Press, 1999: 183; G. Aditjondro, «Guns, Pamphlets and Handie-Talkies - How the Military Exploited Local Ethno-Religious Tensions in Maluku to Preserve their Political and Economic Advantages», in I. Wessel \& G. Wimhoefer (eds), Violence in Indonesia, Berlin, Humboldt University Press, 2001: 117; K. Conboy, Kopassus ..., op. cit.: 166-186, 236-238, 280, 290-292, 304-316; J. Martinkus, A Dirty Little War, Sydney, Random House Australia, 2001: 58-59; H. Macdonald (ed.), Masters of Terror - Indonesia's Military and Violence in East Timor in 1999, Canberra Paper 145, Canberra, 2002; H. Myrttinen, "Alte "neue" Kriege - Die Privatisierung der Gewalt in Indonesien», in D. Azzelini \& B. Kanzleiter (eds), Das Unternehmen Krieg - Paramilitärs, Warlords und Privatarmeen als Akteure der Neuen Kriegsordnung, Berlin, Assoziation A, 2003: 134-135. On similarities to methods in other Southeast Asian and Latin American Conflicts, see B. CARR \& E. Mckay (eds), Low Intensity Conflict - Theory and Practice in Central America and South East Asia, La Trobe University Institute of Latin American Studies and Monash University Centre of Southeast Asian Studies, 1989, and M. Gonzales, «Nachhaltig zum Schweigen gebracht - Paramilitarismus, 
The conflict took a new turn in 1998, when the reformasi-movement ${ }^{10}$ in Indonesia brought an end to the dictatorship of General Suharto. Suharto's hand-picked successor, B.J. Habibie took the unprecedented step of offering the East Timorese people an UN-supervised referendum on independence or special autonomy within Indonesia. The political process was flanked by a new military development, with the Indonesian armed forces setting up, training, financing and arming militia groups in the territory, using them as proxies in a violent campaign of intimidation before the August 1999 referendum $^{11}$. Following a clear majority vote for independence, the pro-Indonesian militias, supported by Indonesian security forces, destroyed around 70\% of the territory's buildings, forcibly deported a third of the population and killed an estimated 2000 people, not to mention those wounded and sexually assaulted ${ }^{12}$.

The wave of militia violence led to an international outcry and an intervention by UN peacekeepers. The territory was the administered by the UN for two years before Timor Leste became independent.

\section{Concepts of Violent Masculinity}

Masculinities, like femininities, are actively constructed and are neither fixed nor monolithic. They can often be contradictory, sending different messages to different audiences. As I have argued elsewhere ${ }^{13}$, violent masculinities can be regarded as enactments which have the aim of reassuring the male himself and «his» side while simultaneously intimidating the «other» side into submission. These enactments are limited spatially and temporally - a policeman can, for example, wield his power and torture detainees during the day, be simultaneously subservient to his superiors and can be a loving father and respected member of his village society in the evening.

Violent masculinities come in different forms. The readiness to use violence can come out of a warrior/protector concept embedded in local traditions; it can be a form of protest; be part of a institutionalised, militarised view of masculinity, e.g. in the case of members of security forces; or it can be a more indirect form

Gewalt und Geschlecht in Guatemala», in D. Azzelini \& B. Kanzleiter (eds), Das Unternehmen Krie ..., op. cit.: 85-98.

${ }^{10}$ Reformasi - Indonesian for reforms - was the rallying cry and subsequently the name given to the pro-democracy movement which toppled Suharto.

${ }^{11}$ Human Rights Watch, Background: The Indonesian Army and Civilian Militias in East Timor, New York, HRW, 1999; H. Macdonald, Masters ..., op. cit.; Serious Crimes Unit, Brief in Support of the Application for the Issuance of an Arrest Warrant for Wiranto - Case $\mathcal{N}^{\circ} \# 5 / 2003$ Deputy General Prosecutor vs. Wiranto and Others, Dili, 2003.

${ }^{12}$ H. Carvalho et al., Timor - O Insuportável Ruído das Lágrimas, Porto, Campo das Letras, 2000; I. Cristalis, Bitter Dawn - East Timor, A People's Story, London, Zed Books, 2002: 214-271; «West Timor: Jakarta's militia terrorise refugee camps», Green Left Weekly, Sydney, 12 of September, 2001; «Traumatized East Timorese Women», The Guardian, London, 30 of July, 2001; J. Martinkus, A Dirty..., op. cit.: 214-347; Serious CRImes Unit, Brief in Support of . .., op. cit.

${ }^{13}$ H. Myrttinen, «Pack Your Heat and Work the Streets - Weapons and the Active Construction of Violent Masculinities», Women and Language, XXVII (2), 2004. 
of violence, e.g. in the case of the political and economic elite benefiting from the violence while not being directly and personally involved in perpetrating $\mathrm{it}^{14}$. The men may or may not take part in the violence voluntarily. The may be coerced to join in, the might seek social or economic benefits or they might even enjoy wielding power ${ }^{15}$.

A common denominator for violent masculinities is that «manliness» is equated with the sanctioned use of aggression, force and violence ${ }^{16}$. Extreme cases can be labelled as enactments of «hypermasculinity». In this context, I use the term to indicate a type of masculinity that is based on an overt display of physical strength and the readiness in the use of violence and of heterosexual prowess, or, as Mosher ${ }^{17}$ defines it, «a personality construct reflecting extreme involvement in and acceptance of the traditional male gender role», a system of ideas

«forming a worldview that chauvinistically exalts male dominance by assuming masculinity, virility, and physicality to be the ideal essence of real men, who are adversarial warriors competing for scarce resources (including women as chattel) in a dangerous world» ${ }^{18}$.

In Timor Leste, all of these forms and manifestations of violent masculinity have been - and still are - visible.

While on the eve of the Indonesian invasion, Timor Leste was still very much steeped in tradition, the 25 years of conflict and of Indonesian occupation have inevitably changed Timorese society profoundly. The rural society and its norms as described by David Hicks ${ }^{19}$ as he experienced it in the late 1960s-early 1970s was still very much untouched by modernity. The Indonesian invasion changed this, bringing with it not only helicopter gunships and napalm, but also paved roads, electricity, compulsory education in a new language (Bahasa Indonesia), family planning, television, a money-based economy and new social norms.

\section{Manifestations and constructions of Violent Masculinity in Timor Leste}

In this article, I have roughly divided the manifestations of violent masculinity visible during the conflict and post-conflict based on the division of the Timorese in the conflict, reflecting the various «cultures» of violent masculinity within the

${ }^{14}$ R. Connell, The Men and The Boys, Cambridge, Polity Press, 2000: 29-32; H. Myrttinen, «Pack...», op. cit.

${ }^{15}$ C. Dolan, «The Proliferation of "Small Men": Exploring the Demand Side of the Small Arms Question», in D. Zarkov (ed.), Gender, Violent Confict, Development: Challenges of Practice, Den Haag, Institute for Social Sciences, [forthcoming]; A. Jones, «Gender and Ethnic Conflict in exYugoslavia», Ethnic and Racial Studies, XVII (1), 1994: 115-134.

${ }^{16}$ L. BRyson, «Sport and the Maintenance of Masculine Hegemony», Women's Studies International Forum, X (4), 1987.

${ }^{17}$ D. Mosher, «Macho Men, Machismo, and Sexuality», Annual Review of Sex Research, 2, 1991: 199-247.

${ }^{18}$ D. Mosher \& S. Tomkins, «Scripting the Macho Man: Hypermasculine Socialization and Enculturation», Fournal of Sex Research, 25, 1988: 60-84.

${ }^{19}$ D. Hicks, Tetum Ghosts and Kin..., op. cit. 
groups. Inevitably, this will lead to generalisations that may well do injustice to the individual cases and thus these should only be regarded as rough sketches, drawn up for the sake of an argument.

Concentrating on the Timorese actors means that those non-Timorese actors which have also played a defining role in the conflict, such as the Indonesian security forces or the foreign militaries which made up the UN peacekeeping forces will be given less prominence. In part, they will be touched upon in as far as they are relevant to the constructions of Timorese masculinities, in part the reader will be referred to elsewhere ${ }^{20}$.

Two examples of elements of the old traditions which have survived and which can be seen to have an impact on constructions of violent masculinity are the brandishing of traditional weapons in public, e.g. as part of demonstrations and cockfighting, which with its symbolic (and real) connections to blood, violence and sexuality, has been a traditional rite of passage from boyhood to manhood ${ }^{21}$.

Indonesian occupation brought with it both Indonesian and international role models. Two Indonesian role models whose influence could be seen were the «pemuda» and the «preman». The pemuda concept has its roots in the Indonesian War of Independence and refers in this context mainly to young revolutionaries known for their daring and recklessness. The dress code and demeanour of the pemuda is regularly invoked for example by youthful supporters of political parties in Indonesia and was also, to an extent, visible as an influence with the East Timorese militias. According to Colombijn, the pemuda-subculture is characterised as a social space for young people, especially men, to act in a violent, reckless and fierce manner on behalf of a higher cause ${ }^{22}$.

The preman is a glorified neighbourhood thug, displaying a hard, street masculinity. While engaging in illegal activities such as gambling and extortion, preman can also provide a kind of vigilante security service to the neighbourhood. Since the fall of Suharto, Indonesian political parties and mass movements have increasingly drawn on preman to act either as «thugs for hire» or as more respectable security guards, leading to complaints about a «premanisation» of Indonesian political culture ${ }^{23}$. Small-time criminals from the large towns of Java

${ }^{20}$ For a rather uncritical «inside» view of the Indonesian security forces involved in the occupation of Timor Leste, see K. Conboy, Kopassus ..., op. cit.: 205-276, 305-316; for more critical and valuable views, see G. Aditjondro, Ninjas..., op. cit., and R. CribB, «From total people's defence to massacre - Explaining Indonesian military violence in East Timor», in F. ColombijN \& J. Lindblad (eds), Roots of Violence in Indonesia, Singapore, Institute of Southeast Asian Studies, 2002: 227-242. For the impact of the UN peacekeeping mission in Timor Leste from a gender perspective, see S. Koyama \& H. Myrttinen, «Long-term Gendered Impacts of the UN Missions in Timor Leste», in C. Aor \& C. de Coning (eds), Unintended Consequences of Peacekeeping Operations, Tokyo, United Nations University Press; [forthcoming].

21 D. Hicks, Tetum Ghosts and Kin ..., op. cit.: 102-111.

${ }^{22}$ F. Colombijn, «What is so Indonesian about violence?», in I. Wessel \& G. Wimhoefer (eds), Violence in Indonesia, Berlin, Humboldt University Press, 2001: 35-36.

${ }^{23}$ H. Nordholt, «A genealogy of violence», in F. Colombijn \& J. Lindblad (eds), Roots of Violence in Indonesia, op. cit.: 49-52; K. van Dijk, «The Privatisation of Public Order - Relying on the Satgas», in I. Wessel \& G. Wimhoefer (eds), Violence in Indonesia, Berlin, Humboldt University Press, 2001: 152-167. 
have also been recruited by members of the security forces to join militia groups in conflict areas, such as in Sulawesi and Maluku².

A further Indonesian influence was the institutionalised, militarised violent masculinity displayed by the Indonesian security forces. The most direct impact of this on Timorese constructions of violent masculinity was of course as «the other» for the Falintil guerrillas and as the direct role model and teacher for the proIndonesian militias.

Even though the territory remained closed to the outside world for the larger part of the period of Indonesian occupation, international influences also seeped in. Through globalised popular culture, role models such as Rambo or ninjas became household terms in Timor Leste as well. For example, the Indonesian death squads, which included Timorese members, of the late 1980s and early 1990s called themselves ninjas. ${ }^{25}$ Globalised iconic figures of just (male, vaguely leftist) rebellion such as Bob Marley and Ernesto «Che» Guevara were and remain popular in Timor Leste and were identified mainly with the pro-independence cause.

\section{Falintil}

Following their near-defeat and the separation from their mass base in 1979-1980, the Falintil guerrillas continued their armed struggle as small groups in the mountains for the following 20 years. They were supported in their struggle by villagers and also by the so-called «clandestine front» in the cities, in which students played a prominent role. The vast majority of the armed fighters were men, though some women took up arms as well. Mostly, though, women were involved in supporting activities, such as working as messengers (estafetas), bringing supplies to the fighters, cooking and cleaning. Female fighters formed their own organisation within Falintil, the OPMT (Organização Popular da Mulher Timorense), which, in addition to providing support to the fighting force and occasionally engaging in combat activities. The OPMT also campaigned for women's rights within the Falintil movement ${ }^{26}$.

In the mountains, the Falintil developed their own autochtonous warrior culture, drawing on traditional Timorese concepts, Portuguese and Catholic influences and socialist ideals of equality. In terms of gender relationships, this meant breaking, at least in theory, with patriarchy and with the traditional system of polygamy. Officially, and in the education given by the Falintil to the local population, especially during the early years of the conflict, gender equality was stressed ${ }^{27}$. In practice, however, gender roles often remained within their traditional boundaries ${ }^{28}$.

Being an armed formation, being a male member of the Falintil almost always meant carrying and using arms. While most of the violence was directed strictly against the Indonesian security forces, the Falintil, as any guerrilla formation, were

${ }^{24}$ G. Aditjondro, Guns, pamphlets..., op. cit.: 119-122.

25 G. Aditjondro, Ninjas ..., op. cit.: 189-190.

${ }^{26}$ C. Pinto \& M. Jardine, East Timor's Unfinished Struggle - Inside The Timorese Resistance, Boston, South End Press, 1997: 47-53.

27 Ibid.: 47.

28 I. Cristalis, Bitter Dawn..., op. cit.: 182-191; J. Martinkus, A Dirty Little..., op. cit. 
not above using violence against civilians collaborating with the Indonesian authorities and «detractors» within their own ranks, especially during the initial phases of the conflict.

The Falintil used Portuguese as their language of communication and kept in close contact with the Catholic Church, though especially in the earlier years there were more hard-line socialist leanings within the movement. Over the years, some of the smaller Falintil groups, above all the eccentric Sagrada Familia group, developed an increasingly mystical outlook, mixing traditional beliefs with Catholic imagery $^{29}$.

One of the reasons that Bob Marley and reggae music became clandestine, subversive signs of support for the Falintil in the urban areas was the visual similarity between the attire and hairstyle of the guerrilla and the rasta-movement, in addition to the rebellion against stifling norms inherently projected into reggae music and its icons. In Timorese graffiti and political art, Falintil commander (and current President) Xanana Gusmão was often depicted in a manner reminiscent of the iconic images of Che Guevara and was compared with Nelson Mandela.

\section{Militias $^{30}$}

As mentioned above, the pro-Indonesian militia groups were established by the Indonesian security forces towards the end of the 1990s to act as proxies and to «Timorise» the conflict. The militias were founded, organised, trained and financed by the Indonesian occupation authorities and security forces but compromised largely of Timorese males. A small number of women were also involved, but mainly as secretarial staff or as participants in militia-organised mass demonstrations.

The violent masculinity displayed by the militia groups was not dissimilar in style, attire and degree of violence to the hypermasculinity visible in other conflicts of the 1990s and beginning of the millennium, be it in the Balkan Wars, Colombia, Sierra Leone or Chechnya.

While many of the militia members were coerced into joining or did so as a survival strategy, many of the «hardcore» militia members did so out of conviction, be it political or otherwise. Joining the violent militia brought with it economic benefits, both directly through the pay given to militia members and indirectly through the prospect of looting ${ }^{31}$. The «glamour» gained through the notoriety and prominence associated with the violent manifestation of hypermasculinity may also have been an incentive for some to join.

It is important to note that while the Indonesian security forces were able to draw upon a pool of mostly young men willing to join - and coerce others into joining - militia masculinity was actively constructed through the military training given to them and by drawing upon violent male role models, some of which

29 Ibid.: 171-172, 200.

${ }^{30}$ For a more thorough look at violent militia masculinity, see H. Mrrttinen, «Sketching the Militias - On Constructions Militia Masculinity in the Timor Leste Conflict», in D. Zarkov, Gender, Violent Conflict, Development: Challenges of Practice, Den Haag, Institute for Social Sciences [forthcoming].

31 I. Cristalis, Bitter Dawn..., op. cit.: 142. 
were imported from Indonesia (e.g. pemuda- and preman-masculinities) and methods used in «counterinsurgency» warfare in other parts of Southeast Asia and Latin America. Thus the violence was not a «natural» outpouring of masculine violence or a culturally conditioned response ${ }^{32}$, but one which was actively engineered and planned.

\section{Givilians}

As in most armed conflicts, civilians bore the brunt of the violence in Timor Leste. Both men and women were targeted, men as suspected Falintil members, women as suspected OPMT members. The violence against civilians was carried out almost exclusively by the Indonesian security forces, and after 1998, by the pro-Indonesian militias. Much of this violence was sexualised in nature. Men and women were sexually abused and raped, women, especially spouses or family members of known members of the resistance, were forced into marriages with army officers or into sexual slavery, torture was often sexualised and corpses with mutilated genitalia were displayed in public ${ }^{33}$.

In addition to this conflict-related violence, however, there was also another level of violence. Figures are difficult to come by as victims would have been reluctant to report the crimes to the Indonesian occupation authorities, but based on anecdotal evidence, levels of domestic and sexualised violence were very high amongst the civilian population ${ }^{34}$.

\section{Violent masculinities in the post-conflict situation}

The end of the open conflict in Timor Leste towards the end of 1999 and the disarming and demobilisation of the Falintil and of those militia members who remained in the territory did unfortunately mean a demobilisation of violent masculinities. Sexualised violence, perpetrated mostly by men against women, remains a serious problem. During the time of the UNTAET administration, up to $40 \%$ of reported crime was sexualised and domestic violence. The figure is a minimum figure, as given the nature of the crime, much of it remains unreported. Also, cases leading to the death of the victim would have been classified as murders ${ }^{35}$.

As several Timorese and Indonesian observers have $\operatorname{argued}^{36}$, the patriarchical social structure, the years of conflict and the militarised education given during

32 This was the argument put forward by Gen. Makarim, the senior Indonesian officer in Timor during the militia violence who claimed the rampage was traceable to «Indonesian amok culture», in G. Robinson, «The fruitless search for a smoking gun», in F. Colombijn \& J. Lindblad (eds), Violence..., op. cit.: 244.

33 G. Aditjondro, Ninjas..., op. cit.: 182-183; P. Carey, «Dimensions of Domination Institutionalised violence against women during the Indonesian occupation of East Timor (19751999)», in L. Wessel \& G. Wimhoefer (eds), Violence . ., op. cit.: 185-209 and comissão DE ACOLHIMENTO, VERdAdE E REGONGILIÇÃo DE TIMOR LESTE, Final Report, forthcoming pending approval by parliament.

34 Interview with U. Alves, Fokupers, Dili, 6 of may, 2004.

35 Interview with UNPOL Staff, Dili, 28 of April, 2004.

36 Interviews with S. Abdullah, INSIST, Yogyakarta, 5 of February, 2004; L. Akara, Associação Mane Contra Violência, Dili, 28 of April, 2004; U. Alves, Fokupers, Dili, 6 of May, 2004. 
the Suharto-era have left many men with no other tools at their disposal for airing legitimate social, economic or political Martial arts groups and veterans' organisations have become pools for disgruntled men and form a very real potential source of instability ${ }^{37}$.

During the UNTAET period, the new security forces, the new police force PNTL (Policia Nacional de Timor Leste) and the new national armed forces F-FDTL (Falintil-Forças de Defesa de Timor Leste). The staff was recruited from demobilised Falintil, Timorese members of the Indonesian police (PNTL only) and new recruits. Both forces were given extensive training by the UN, including on issues of human rights and gender sensitivity. Hence, it comes as somewhat of a disappointment that after the extensive training given to them, there are still reports of sexual harassment and even gang rape by members of the security forces ${ }^{38}$. Furthermore, rivalry between the two forces has led to scuffles between the two, adding to potential instability in the country ${ }^{39}$.

A further highly visible factor in post-conflict Timor Leste has been the presence of up to over 12000 international UN staff, up to around 11000 were in uniform, in addition to which there were thousands of international NGO workers, contractors and media. These brought with them a range of attitudes to gender issues, often different from those which Timorese society had been accustomed to $^{40}$. The sudden influx of «internationals» has mainly been seen as liberalising gender attitudes, especially in the urban areas. Some of this has been intentional, as the UN missions did have a specific mandate to increase gender equality, while some of it has been unintentional, such as the impact on the sex industry. There have also been cases of sexual misconduct and sexualised violence committed by UN staff. In trying to promote gender equality, the UN mission has also needed to overcome internal resistance to the issue. As one UN police officer interviewed by the author stated, «its sometimes difficult for the UN police to effectively train the Timorese police in matters of gender sensitivity when some of our [UNPOL] officers come from backgrounds in which gender-based domestic violence is not considered to be a crime».

I hope to have demonstrated in this article that the war and the post-conflict situation have given rise to a number of different forms of violent masculinity in Timor Leste. These masculinities did not come about because Timorese men are culturally disposed to violence or because men are «naturally» violent, but because they were actively constructed in different situations with different goals in mind.

${ }^{37}$ Interviews with PKF and UNPOL Staff, Dili, 24 of April, 2004 and 28 of April, 2004, respectively.

${ }^{38}$ Alola Foundation, Trafficking in East Timor - A Look into the Sex Industry of the Nerwest Nation, Alola Foundation, Dili, 2004; Interview with E. Belo, Alola Foundation, 10 of June, 2004.

${ }^{39}$ E. Rees, Under Pressure - Three Decades of Defence Force Development in Timor Leste 1975-2004, Geneva, Centre for the Democratic Control of the Armed Forces, 2004.

${ }^{40}$ For a more thorough look at the impact of the UN missions from a gender perspective, see S. Koyama \& H. Myrttinen, Long-term..., op. cit. 
Cultural, economic, social, historical and personal factors all played their roles in this construction process.

As constructs, these violent masculinities can therefore also be deconstructed or demobilised. As the case of Timor Leste shows, this does not happen automatically after a conflict ends. Levels of domestic and sexualised violence remain high and men espousing potentially violent enactments of masculinity, be it disgruntled youths or ex-Falintil or members of the new security forces, remain a source of social instability.

The outlook is not, however, altogether bleak. The post-conflict era has also seen the emergence of a vibrant women's movement as well as a nascent men's movement, which seek to find new, non-violent ways of defining what it means to be a man or a woman in Timor Leste.

Henri MYRTTINEN Indonesian Society for Social Transformation (INSIST) Yogyakarta (Indonesia) e-mail: <henri@kepa.fi> 